\title{
HYDRAULICS OF SURFACE POLLUTED WATER - JET IN OPEN CHANNEL FLOW
}

\author{
Nashat A. Ali ${ }^{1}$, Gamal Abozeid ${ }^{1}$, Ali A. Mohamed ${ }^{2}$ and \\ Moustafa S. Darweesh ${ }^{3}$. \\ ${ }^{1}$ Professors of hydraulics \& water resources, Civil Eng. Dept., Assiut Univ., \\ 71516 Assiut. \\ ${ }^{2}$ Associate Professor, Civil Engineering Dept., Assiut University, 71516 Assiut \\ ${ }^{3}$ Demonstrator, Civil Eng. Dept., Assiut University, 71516 Assiut
}

(Received October 27, 2009 Accepted December 12, 2009)

\begin{abstract}
Presented in this paper are the results of an intensive experimental program for studying the influence of jet inclination, velocity ratio, pollutant type and initial concentration on hydraulic characteristics of polluted surface water jet in open channel flow. Polluted jet is injected from a sided polluted source with different angles of inclination to mainstream direction. The polluted water is prepared by adding two types of chemicals (sodium chloride and pfennig) with different concentrations to fresh water. The initial jet velocity is varied to cover a range of velocity ratio $R$ from 2.73 to 10.0. For each velocity ratio, the solute concentration is changed to take 800, 1050, 1382.23, 1440, 1780 and 2320 p.p.m .The centerline jet trajectory, velocity decay, pollutant dilution and the width of polluted area are measured. The velocity is measured by a calibrated current meter while the jet coordinates and water depths are measured using point gages. Samples are taken from jet centerline to measure the jet concentration. The concentrations are measured using Conductance /Total_Dissolved Solids Model 76.

The factors influencing the problem are normalized with the help of dimensional analysis theory. The analysis of the results revealed that the characteristics of a polluted water jet in cross-flow depend mainly on jet to main stream velocity ratio and jet inclination to the main stream. Also, the decay of the velocity and dilution of pollution concentration are mainly depending on the studied parameters. The type of pollution does not affect these characteristics. Equations have been developed for the correlation of the experimental results. A comparison between the results of present study and those from previous studies are carried out. These comparisons give a reasonable agreement.
\end{abstract}

KEYWORDS: Open channels, Surface discharging jets, Pollutant concentration and type.

\section{INTRODUCTION}

Turbulent jets discharging from circular outlets held inclined to a moving stream (as free jet) have received an attention in the past few decades [1,4,8-19]. Abozeid [1] presented a laboratory study on the factors influencing the characteristics of surface 
discharge of heated water jet in an open channel. Chassaing et al. [4] investigated the physical characteristics of jets in a cross-stream. Jirka [8] reported that, the jet penetration depends mainly on the velocity ratio R. One effective way of achieving proper mixing and dilution is to discharge the effluent near the river-bed as a turbulent free jet perpendicular to the river flow $[6,9,17]$. Another way of achieving this dilution could be to discharge the effluent from the river bank as a surface jet, tangentially to the river bed and directed perpendicular to the river flow [15]. Keffer and Baines [10] and Moussa et al. [13] observed that the jet velocity and temperature trajectories were mainly governed by the momentum ratio, while McGuirk and Rodi [11] used a twodimensional depth averaged calculation method utilizing the $\mathrm{k}-\varepsilon$ model to predict the flow in the near field of a jet discharging from the side of a straight channel. Wright [18] presented a model of a round buoyant jet discharges normally to an ambient crossflow. The behavior was analyzed by considering it to be a source of kinematic momentum and buoyancy flux. Mohamed [12] presented the results if an experimental investigation on heated wall jets in a cross-flow and stated that the diffusion of heated wall jets discharged at right angles into a cross flow depends mainly on the velocity ratio and the shape of the nozzle. Ibrahim and Gutmark [7] conducted their experiments in a subsonic closed loop wind tunnel, and studied the effect of velocity ratio on the trajectory of the jet and compared his results with Yuan et al. [19] to confirm that jet trajectories rise and penetrate deep with increasing the velocity ratio.

Present study is performed experimentally to investigate the influence of pollutant type, velocity ratio and angle of inclination of the jet to main stream direction on the flow characteristics of the polluted surface discharging jet in a cross flow.

\section{NOMENCLATURE}
$B \quad$ Flume bed width
b Width of the outlet
C Jet concentration along the centerline
$\mathrm{C}_{\mathrm{j}}$ Initial concentration of the jet
$\mathrm{C}_{\mathrm{o}} \quad$ Mainstream concentration
D Channel depth
D Outlet diameter
$d_{m} \quad$ Maximum depth at which the jet will reach if it is not restricted by the bed
$F_{d} \quad$ Densimetric Froud number
G Gravitational acceleration
H Outlet depth
$\mathrm{R}$ Velocity ratio $=\mathrm{V}_{\mathrm{j}} / \mathrm{U}_{\mathrm{o}}$

$\mathrm{x}, \mathrm{y} \& \mathrm{~s}$

$\mathrm{X} \& \mathrm{Y}$
$\mathrm{S}$

$\mathrm{U}_{\mathrm{o}}$

$\mathrm{V}_{\mathrm{j}}$

$\mathrm{V}_{\mathrm{m}}$

$\mathrm{W}_{\mathrm{y}}$

$\lambda$

$\theta$

$\mu$

$\rho_{\mathrm{j}}$

$\rho_{\mathrm{o}}$

Distance along the jet centerline

Mainstream mean velocity

Initial velocity of the jet

Maximum jet velocity along C.L.

Distances along the jet

Cartesian coordinates in the horizontal plane of jet C.L.

$\mathrm{W}_{\mathrm{y}} \quad$ Jet width

$\lambda \quad$ Aspect ratio $=\mathrm{b} / \mathrm{h}$

$\theta \quad$ Inclination angle of the outlet

Dynamic viscosity of ambient fluid

$\Delta \rho \quad$ Initial density difference 


\section{EXPERIMENTAL SET-UP}

The experiments were conducted in a tilting flume located in the hydraulics Laboratory of Civil Engineering Department, Assuit University. A schematic representation of the experimental set-up is shown in Fig. 1. A rectangular open flume having $600 \mathrm{~mm}$ wide, $250 \mathrm{~mm}$ deep $3.00 \mathrm{~m}$ long was used as a main open stream. The mainstream flow was supplied from an elevated constant head tank through a pipeline and was regulated and measured by means of a gate valve and orifice-meter located on the delivery pipeline, respectively. The water depths were controlled using a downstream tailgate. A circular nozzle issuing the side surface flow jet is located at $1.50 \mathrm{~m}$ from the flume inlet section. The nozzle set to take $45^{\circ}$ and $90^{\circ}$ to the direction of mainstream. The lateral emanating polluted water-jet was supplied from an elevated constant-head tank containing polluted water. The polluted water was regulated and measured using a valve and orifice meter located at the supply pipe respectively (see Fig. 1). A currentmeter with $5 \mathrm{~mm}$ diameter was used to measure the velocities. The measurements of mean concentration of the pollutant along the jet trajectory in the mainstream were made using Conductance/Total_Dissolved Solids Model 76 which measure the concentration for a range from 0 to $10^{4} \mathrm{mg} / \mathrm{L}$. Compacted digital camera was used to take vertical photos for determination the co-ordinates of the polluted wall jet centerline and its spreading in the mainstream by using Auto-cade software program. The measurements were taken at a depth corresponding to the level of the outlet centerline. The trajectory bent as a result of the cross flow was determined by adding a dye to the polluted water. The $x-y$ coordinates of the jet centerline were measured by using point gages and scales.

Procedures: The experiments are achieved to study the influence of jet inclination, velocity ratio pollutant type and initial concentration excess on the mean flow characteristics of the surface discharging polluted jet in a cross flow. The following procedures are followed in performing the experiments:

1. The nozzle of the polluted water supply was fixed and its angle of inclination was set to be $90^{\circ}$ with mainstream direction.

2. The mainstream flow rate and its water depth were regulated to be $13.73 \mathrm{~L} / \mathrm{s}$. and $9.6 \mathrm{~cm}$ respectively.

3. The control valve of polluted water (solute of sodium chloride) was adjusted to give a certain discharge and the concentration was measured. The concentration was changed to be 800,1050,1382.23,1440, 1780 and 2320 p.p.m.

4. Co-ordinates $(x, y)$, velocity, concentration and width of polluted water jet along the jet centerline were measured and a photo by digital camera was taken.

5. The polluted water jet velocity was changed several times to change the velocity ratio $\left(R=V_{j} / U_{o}\right)$ from 2.73 to 10.00 , and step (4) was repeated.

6. The concentration of the polluted water jet was changed and steps from 3-5 were repeated.

7. The angle on inclination was changed to be $45^{\circ}$ and steps from 1-6 were repeated.

8. The type of chemical pollution was changed to be pfennig and steps from $1-6$ were repeated. 


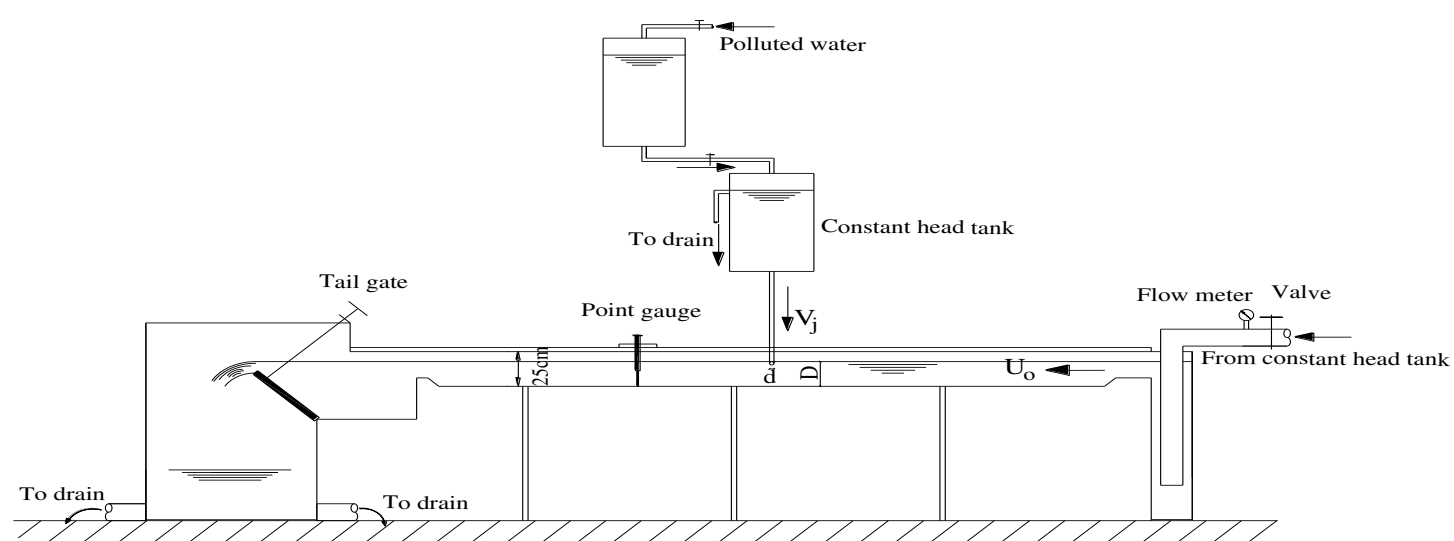

Elevation

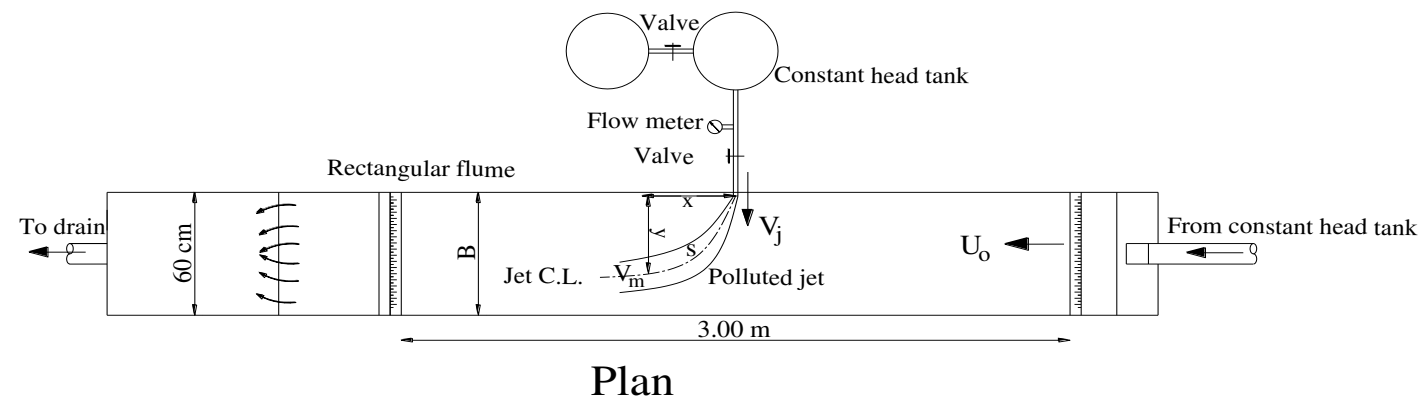

Fig.1: Schematic representation of the experimental set-up.

\section{THEORETICAL APPROACHE}

Theoretical formulation of the characterizing parameters of mean flow behavior of a surface side-discharging jet in a mainstream may be reached by dimensional reasoning. These parameters can have the following functional relationships;

$$
\Phi_{1}\left(B, D, d, \theta, U, V_{j}, V_{m}, C, C_{o}, C_{j}, x, y, s, g, W_{y}, \rho_{o}, \rho_{j}, \mu\right)=0
$$

If $\Delta \rho=\rho_{\mathrm{j}}-\rho_{\mathrm{o}}$ and applying the Backingham's " $\pi$ " theory, in which $\mathrm{d}, \mathrm{U}_{\mathrm{o}}$, and $\rho_{\mathrm{o}}$ are selected as repeated variables representing the geometrical dimensions, flow characteristics and fluid properties respectively, one can have:

$\Phi_{2}\left(\theta, \mathrm{C} / \mathrm{C}_{\mathrm{j}}, \mathrm{C}_{\mathrm{j}} / \mathrm{C}_{\mathrm{o}}, \mathrm{V}_{\mathrm{j}} / \mathrm{U}_{\mathrm{o}}, \mathrm{V}_{\mathrm{m}} / \mathrm{V}_{\mathrm{j}}, \mathrm{x} / \mathrm{d}, \mathrm{y} / \mathrm{d}, \mathrm{s} / \mathrm{d}, \mathrm{W}_{\mathrm{y}} / \mathrm{d}, \mathrm{U}_{\mathrm{o}} \cdot \rho_{\mathrm{o}} . \mathrm{D} / \mu, V_{j} / \sqrt{g d \frac{\Delta \rho}{\rho_{o}}}\right)=0$

in which $V_{j} / \sqrt{g d \frac{\Delta \rho}{\rho_{o}}}=$ densimetric Froud number, $\mathrm{F}_{\mathrm{d}}$ (its effect is included in the effect of R). So, it may be dropped from equation (2). $U_{0} \cdot \rho_{0} \cdot D / \mu$ is the Reynolds number $\left(R_{e}\right)$. In open channel flow $R_{e}$ has insignificant effect; so it may be dropped from Eq. (2) [2 and 5]. Applying the properties of dimensional analysis and using the method of synthesis [3] one can get:

$$
\mathrm{C} / \mathrm{C}_{\mathrm{j}}, \mathrm{W}_{\mathrm{y}} / \mathrm{d} \text { and } \mathrm{y} / \mathrm{d}=\Phi_{3}(\mathrm{x} / \mathrm{d}, \theta, \mathrm{R})
$$




$$
\mathrm{V}_{\mathrm{m}} / \mathrm{V}_{\mathrm{j}}=\Phi_{4}(\mathrm{~s} / \mathrm{d}, \theta, \mathrm{R})
$$

\section{RESULTS AND DISCUSSIONS}

Surface side discharge of polluted jet in a cross flow in shallow or deep water. It is considered to be shallow if $\left.d_{m} / h\right\rangle 0.75$, while it can be deep if $d_{m} / h\langle 0.75$. The values of $d_{m}$ can be calculated from the following equation [16].

$$
d_{m}=0.353 h F_{d}(\lambda)^{-0.25}
$$

in which $\lambda$ is aspect ratio $=b / h$, where $b$ is outlet width and $h$ is outlet depth.

In the present investigation, the mainstream is considered to be shallow, where $\left.d_{m} / h\right\rangle 0.75$ for all the studied cases. From his laboratory measurements, Abozeid [1] developed the following equation for the jet trajectory in shallow water;

$$
\frac{y}{b}=0.9 \sqrt{R} \lambda^{-0.2}(x / b)^{\beta}
$$

In which $\beta$ is a constant depending on the angle of jet inclination to the mainstream, $\theta$. For $\theta=90^{\circ}$ and $\theta=30^{\circ}, \beta$ equals to 0.5 and 0.3 respectively. Also, Mohamed [12] and Mowad [14] developed the following equations for both the jet trajectory and mean jet width in shallow water respectively;

$$
\begin{aligned}
& \frac{y}{b}=1.55 R^{0.65} \lambda^{-0.25}\left(\frac{x}{b}\right)^{0.35} \\
& \frac{W_{y}}{R d}=0.93\left(\frac{x}{R d}\right)^{0.49}
\end{aligned}
$$

in which $\mathrm{W}_{\mathrm{y}}$ is the jet width. The results of Eqs. (6-8) are compared with the results of the present study. The influence of velocity ratio, angle of inclination of the jet to mainstream, type and initial concentration on flow characteristics such as the jet trajectory, the growth of the jet width and the decay of velocity and the dilution of concentration-excess along the jet trajectory are investigated in this search.

Jet Trajectory: Figure 2 shows a typical plot of $y / d$ values against $\mathrm{x} / \mathrm{d}$ ones for velocity ratio 2.73 and $\theta=90^{\circ}$ as an example. Also, the results of Eq. (6) and Eq. (7) are included. Also, the figure includes the estimated coordinates from photos by using Auto-cade software. From the figure, it is evident that the jet penetrates fast with the increase of $\mathrm{x} / \mathrm{d}$ till a certain value of $\mathrm{x} / \mathrm{d}$, the jet moves with the mainstream flow. Agreements between the results of Abozied [1] and Mohamed [12] and also from the photos with the measured ones could be observed.

Shown in Fig. 3 is a comparison between jet trajectories for $\mathrm{R}=10$ at $\theta=45^{\circ}$ and $90^{\circ}$. It is clear that for $\theta=90^{\circ}$ the jet penetrates deeper than that for $\theta=45^{\circ}$. This may be due to a higher momentum of the penetrated jet associated with $\theta=90^{\circ}$.

Results of $y / d$ versus $\mathrm{x} / \mathrm{d}$ for $\theta=45^{\circ}$ with different values of velocity ratios, $\mathrm{R}$ are presented in Fig. 4. It is noticed that, the penetration of the emanating jet depends on velocity ratio, $\mathrm{R}$. Where jet penetrates deeper with the high values of $\mathrm{R}$ than that with 
small ones. This may be due to the motion carrying the jet further in the transverse $y$ direction is strongly dependent on the momentum of the jet with respect to the momentum of the cross flow, which is controlled by the velocity ratio (R). The best-fit relationship between $y / d$ and $x / d$ for different velocity ratios may be given in the following form:

$$
\frac{y}{d}=a R^{c}(x / d)^{e}
$$

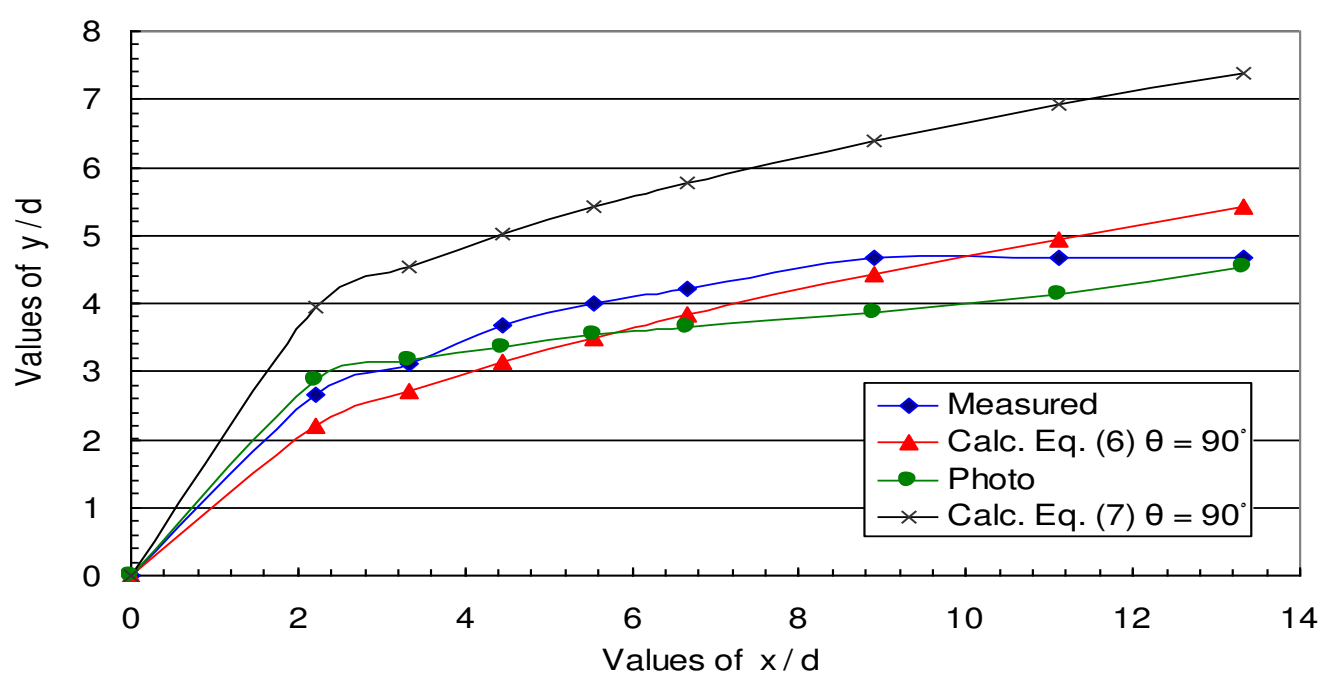

Fig. 2: Relationship between (y/d) and $(\mathrm{x} / \mathrm{d})$ for $\mathrm{R}=2.73$, and $\theta=90^{\circ}$.

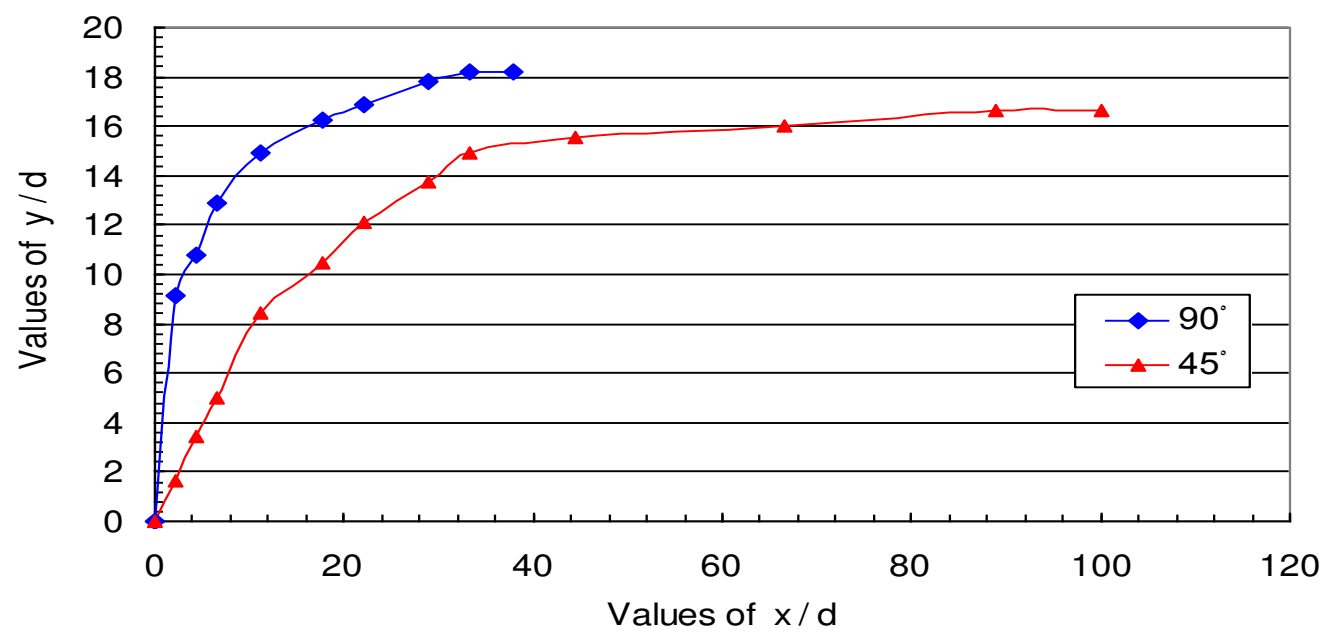

Fig. 3: Influence of jet inclination to the mainstream on jet trajectory for $R=10.00$. 


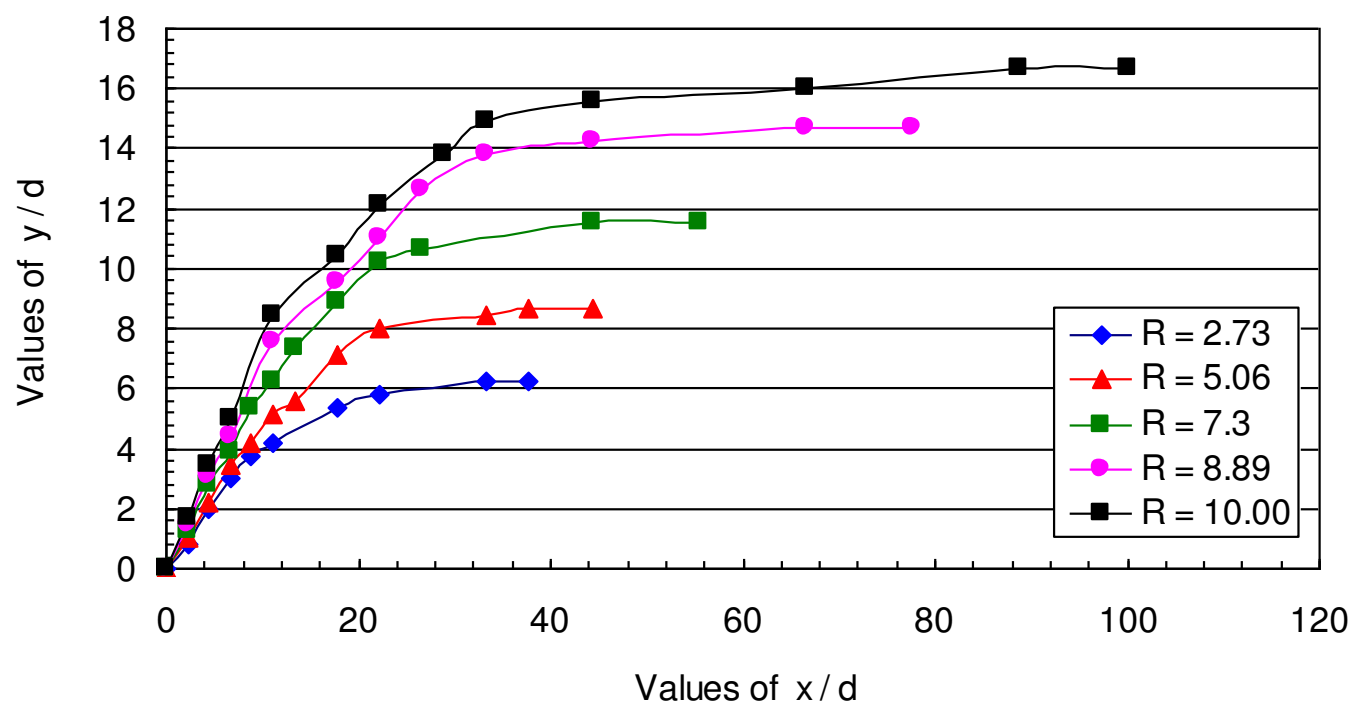

Fig. 4: Relationship between $(\mathrm{y} / \mathrm{d})$ and $(\mathrm{x} / \mathrm{d})$ for different values of $\mathrm{R}$ at $\theta=45^{\circ}$.

where a, $\mathrm{c}$ and e are parameters depending on the jet inclination to mainstream flow direction, $\theta$. Values from this research are shown in Table (1).

Table (1) Coefficients a, c and e in Eq. (9).

\begin{tabular}{|c|c|c|c|}
\hline$\theta^{\circ}$ & $\mathrm{a}$ & $\mathrm{c}$ & $\mathrm{e}$ \\
\hline 90 & 0.92 & 0.84 & 0.35 \\
\hline 45 & 0.78 & 0.6 & 0.35 \\
\hline
\end{tabular}

Centerline Velocity Decay: The centerline velocities were measured at a depth corresponding to the outlet centerline from mainstream water surface. The jet velocity is normalized as $\mathrm{V}_{\mathrm{m}} / \mathrm{V}_{\mathrm{j}}$. Shown in Fig. 5 are the plots of the values $\mathrm{V}_{\mathrm{m}} / \mathrm{V}_{\mathrm{j}}$ against s/d ratios for different velocity ratios at $\theta=90^{\circ}$. It is seen from the figure that for all velocity ratios, $\mathrm{V}_{\mathrm{m}} / \mathrm{V}_{\mathrm{j}}$ decreases sharply with increasing of the normalized distance $\mathrm{s} / \mathrm{d}$ in the region of maximum deflection of the jet due to the presence of a re-circulation zone in the wake immediately downstream the outlet and this indicating a high rate of entrainment of the ambient fluid in this region. After that the decay becoming slow until $\mathrm{V}_{\mathrm{m}}$ approaches the free stream average velocity, $\mathrm{U}_{\mathrm{o}}$. The value of $\mathrm{V}_{\mathrm{m}}$ reaches to $\mathrm{U}_{\mathrm{o}}$ for $\mathrm{R}=2.73 ; \mathrm{s}=10 \mathrm{~d}$, for $\mathrm{R}=5.06 ; \mathrm{s}=18 \mathrm{~d}$, for $\mathrm{R}=7.30 ; \mathrm{s}=36 \mathrm{~d}$, for $\mathrm{R}=8.89 ; \mathrm{s}=41 \mathrm{~d}$ and for $R=10.00 ; s=45 \mathrm{~d}$ or according to the following form with a correlation coefficient of 0.98 :

$$
\frac{s}{d}=2.84(R)^{1.21}
$$




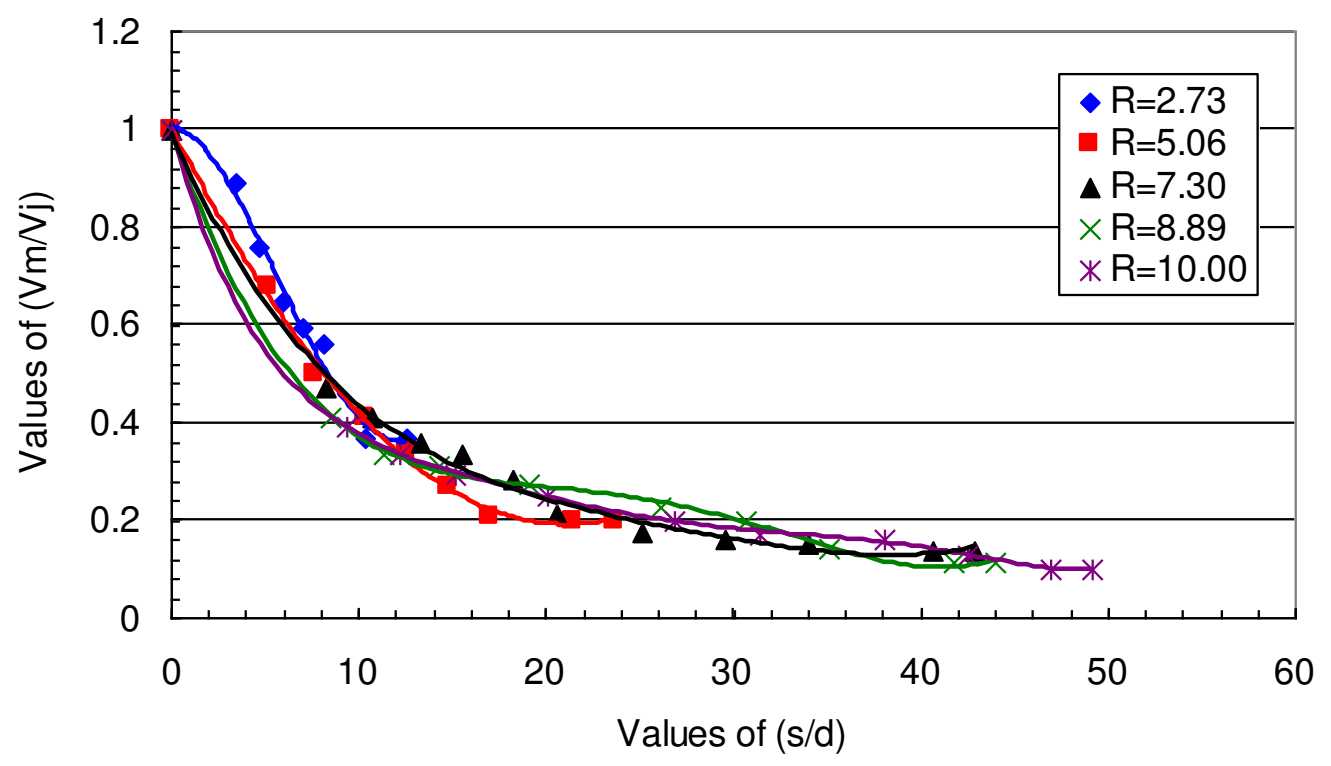

Fig. 5: Decay of centerline velocity-excess for different velocity ratios at $\theta=90^{\circ}$.

Longitudinal and transverse concentrations were measured at a depth corresponding to the level of the jet centerline at several locations of the deflected jet. Pollutant concentration decay is investigated at five different velocity ratios.

Effect of Pollutant Type on Concentration Decay: To show the influence of pollutant type on concentration decay, two types of pollutants are used. These two types are Sodium Chloride and pfennig. The values of $\mathrm{C} / \mathrm{C}_{\mathrm{j}}$ with $\mathrm{x} / \mathrm{d}$ for the two pollutants at $C_{j} / C_{o}=2.94, R=7.30$ and $\theta=90^{\circ}$ are shown plotting as in Fig. 6. It is observed that the concentration decay has the same values and trend for both the two studied types.

Effect of Velocity Ratio on the Concentration Decay: The variation of $C / C_{j}$ with $x / d$ are shown drawing in Fig. 7 for different values of $R$ at $\theta=45^{\circ}$ and $C_{j} / C_{o}=$ 4.34. For $\theta=45^{\circ}$ and $\mathrm{C}_{\mathrm{j}} / \mathrm{C}_{\mathrm{o}}=4.34$, about $75 \%$ of the concentration-excess is rapidly decayed with the increase of $\mathrm{x} / \mathrm{d}$ from 0.0 to 25.0 from the outlet. After that, the decay of concentration-excess slightly decreases with the increase of $x / d$ values. Rapid decay of the concentration-excess in the zone of maximum deflection may due to the volume of fluid entrained is large due to the secondary flow in the wake of the jet, after that, the decay becoming slow. Also, velocity ratios does not have any significant effect on the rate of this decay. Result for $\theta=90^{\circ}$ (not shown here) show that the decay is faster for $\theta=90^{\circ}$ than that for $\theta=45^{\circ}$. This may due to the rapid mix for $\theta=90^{\circ}$. 


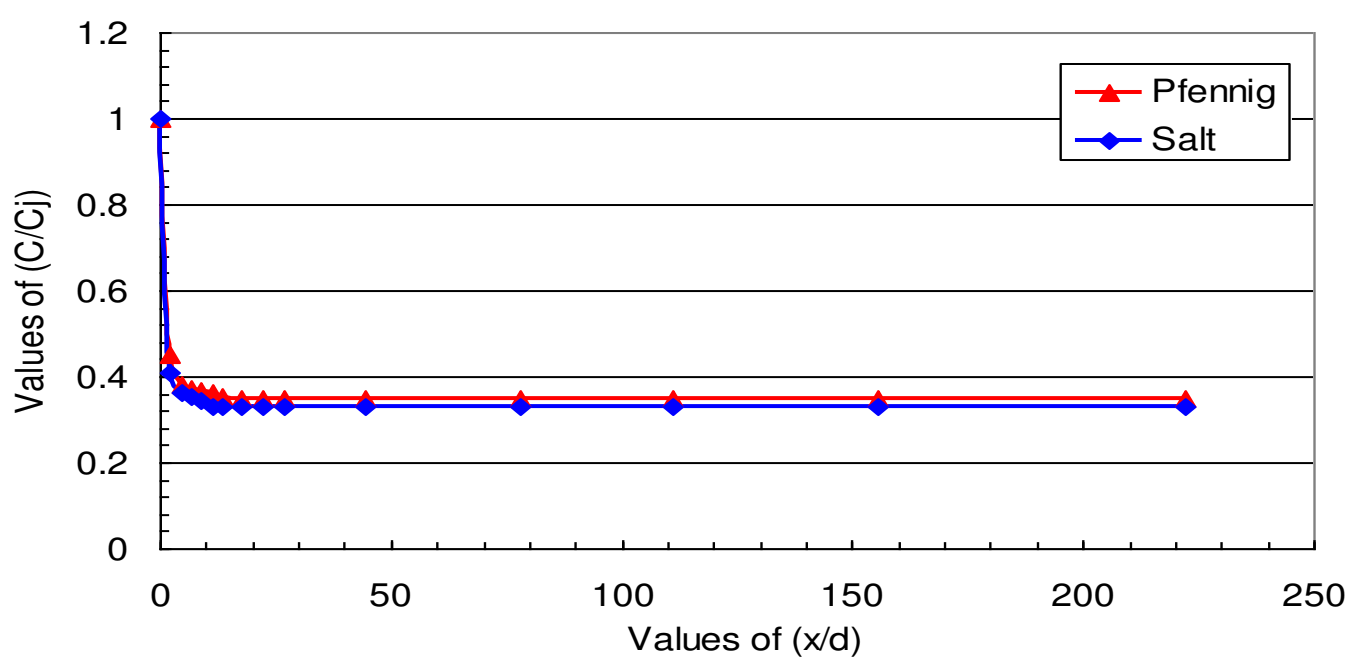

Fig. 6: Relationship between $C / C_{j}$ and $x / d$ for different types of pollutants at $\theta=90^{\circ}$, $\mathrm{C}_{\mathrm{j}} / \mathrm{C}_{\mathrm{o}}=2.94$ and $\mathrm{R}=7.30$.

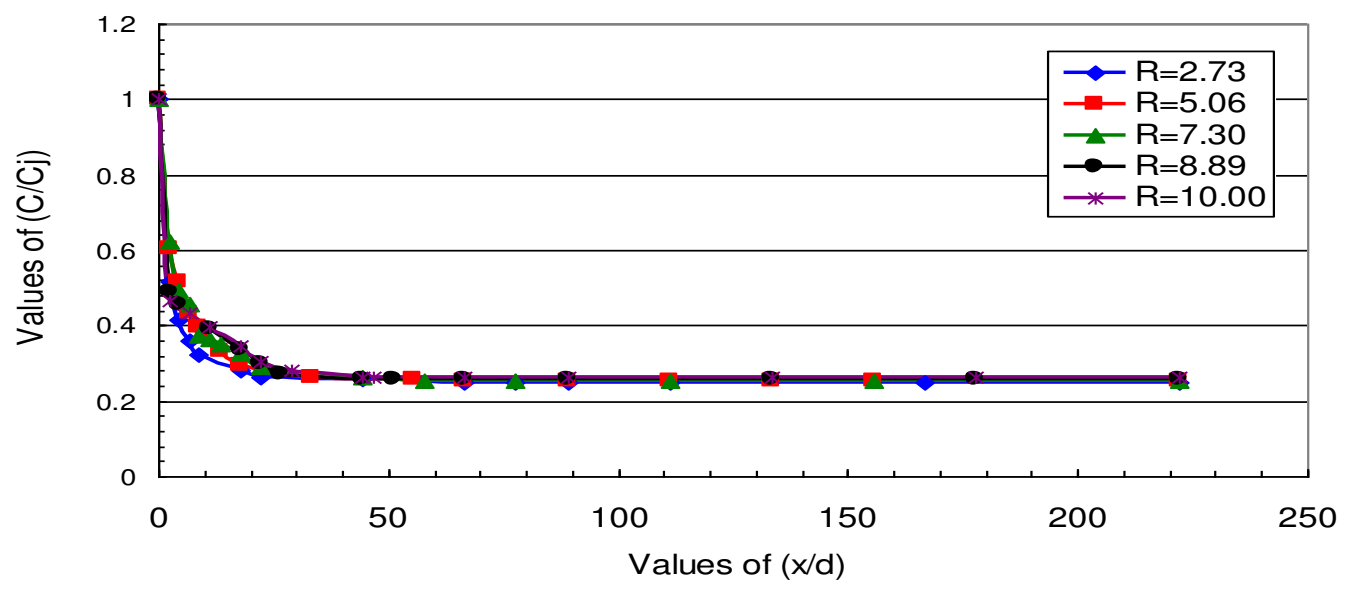

Fig. 7: Relationship between $C / C_{j}$ and $x / d$ for different velocity ratios at $\theta=45^{\circ}$ and $\mathrm{C}_{\mathrm{j}} / \mathrm{C}_{\mathrm{o}}=4.34$.

Effect of Initial Concentration on Concentration Decay: Typical values of $\mathrm{C} / \mathrm{C}_{\mathrm{j}}$ are plotted against these of $\mathrm{x} / \mathrm{d}$ as shown in Fig. 8 for different values of initial concentration-excess $\left(C_{j} / C_{o}\right)$ at $R=2.73$ and $\theta=90^{\circ}$ as an example. A sharp decay in the zone of maximum deflection is seen, after that the rate of decay becoming slow till the concentration reaches to 5\% higher than the ambient concentration. The decay is faster with the initial concentration-excess. About $75 \%$ of the concentration-excess is rapidly decayed with the increase of $x / d$ from 0.0 to 11.0 from the outlet. This is because by increasing the initial concentration-excess, the buoyancy effect tends to make the polluted surface layer spread further away from the discharging outlet. The best fit relationship between $C / C_{j}$ and $x / d$ for different values of $\left(C_{j} / C_{o}\right)$ may be drawn as follows; 


$$
\frac{C}{C_{j}}=f(x / d)^{-0.02\left(C_{j} / C_{o}\right)^{k}}
$$

The values of the parameters $\mathrm{f}$ and $\mathrm{k}$ depend on the angle of inclination as shown in the following table.

Table (2) Coefficients $f$ and $k$ in Eq. (11).

\begin{tabular}{|c|c|c|}
\hline$\theta^{\circ}$ & $\mathrm{f}$ & $\mathrm{k}$ \\
\hline 90 & 0.45 & 1.66 \\
\hline 45 & 0.61 & 1.53 \\
\hline
\end{tabular}

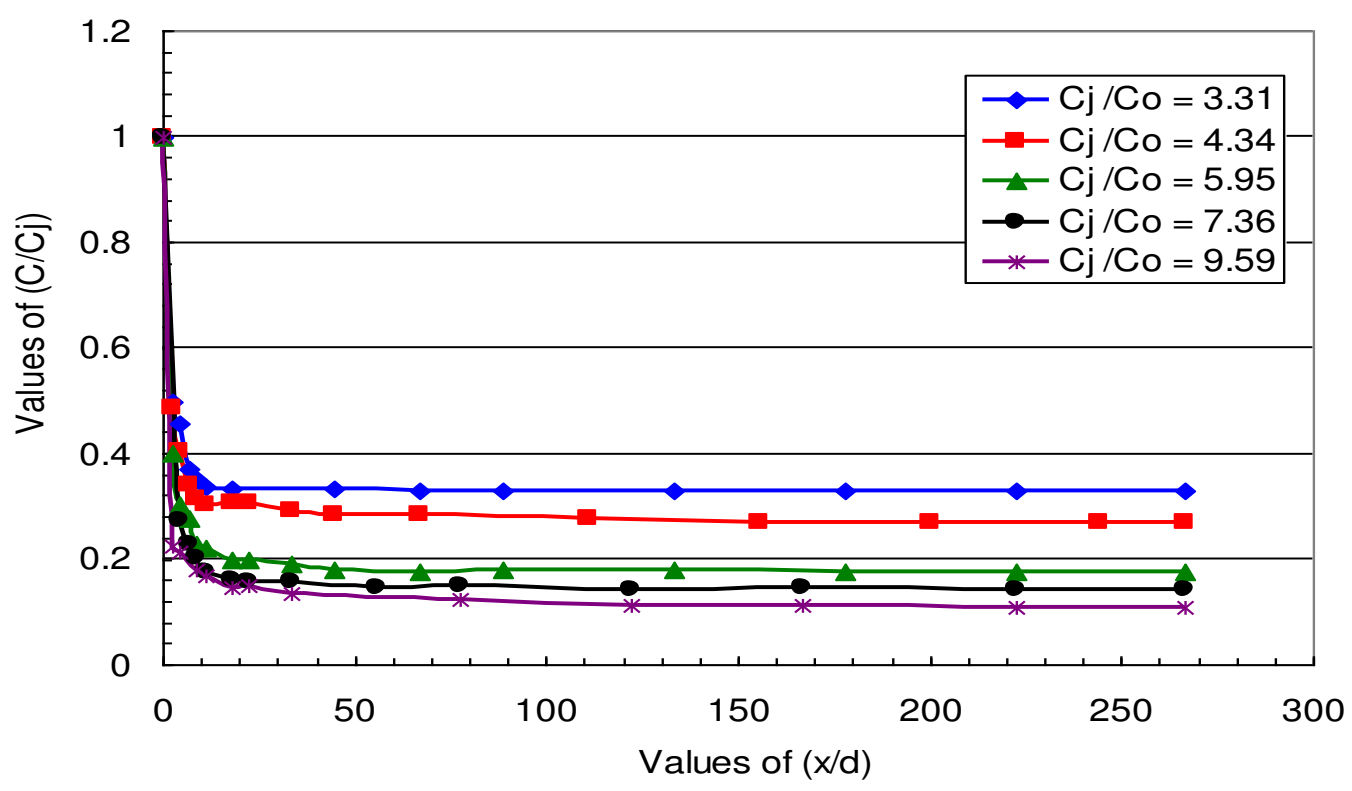

Fig. 8: Relationship between $C / C_{j}$ and $x / d$ for different values of $C_{j} / C_{o}$ at $\theta=90^{\circ}$ and $\mathrm{R}=2.73$.

Jet Width: The importance of studying the growth of jet width $\mathrm{W}_{\mathrm{y}}$ in transverse direction is to predict the polluted area in the main stream. Figure 9 shows the variation of jet width normalized by jet diameter $\mathrm{W}_{\mathrm{y}} / \mathrm{d}$ with normalized distance $\mathrm{x} / \mathrm{d}$ for $\mathrm{R}=8.89$ and $\theta=90^{\circ}$ and $45^{\circ}$. The results of Eq. (9) are also included. It is seen from the figure that the width of the jet increases rapidly with increasing the longitudinal distance along the jet trajectory near the source, then the increasing rate becoming slow with the increase of the distance from the source. Jet width at $\theta=90^{\circ}$ is greater than that at $\theta=$ $45^{\circ}$, which is due to the higher mix at $\theta=90^{\circ}$. A good agreement with results of Eq.(9) is noticed. 


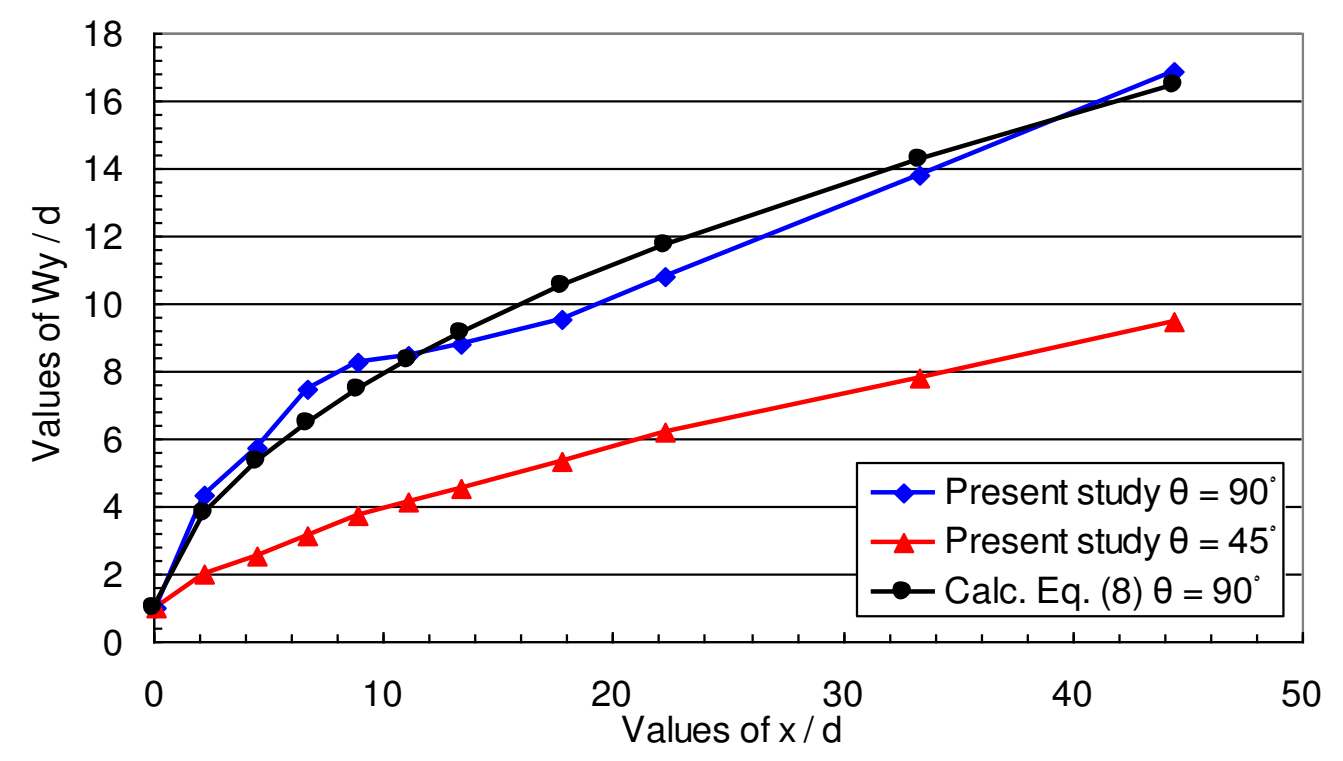

Fig. 9: Influence of jet inclination to the mainstream on growth of jet width for $\mathrm{R}=$ 7.30 .

To study the effect of velocity ratio on the jet width, the values of $\mathrm{W}_{\mathrm{y}} / \mathrm{d}$ are plotted against $\mathrm{x} / \mathrm{d}$ for different velocity ratios and $\theta=45^{\circ}$ as shown in Fig. 10. It is observed that, jet width increases with the increase of the velocity ratio and traveling distance. This is may be due to the increase of momentum flux from the nozzle with the increase of velocity ratio. Then leads to an increase of the entrainment with the cross flow. The variation of the normalized width $\mathrm{W}_{\mathrm{y}} / \mathrm{d}$ with $\mathrm{x} / \mathrm{d}$ for jets in cross stream can be described by the following equation:

$$
\frac{W_{y}}{d}=\alpha[x / d]^{\varepsilon(R)^{\omega}}
$$

where $\alpha, \varepsilon$ and $\omega$ are parameters depending on jet inclination to mainstream flow direction, $\theta$. Their values are given in Table (3) based on the present data.

Table (3) Coefficients $\alpha, \varepsilon$ and $\omega$ in Eq. (12).

\begin{tabular}{|c|c|c|c|}
\hline$\theta^{\circ}$ & $\alpha$ & $\varepsilon$ & $\omega$ \\
\hline 90 & 3 & 0.15 & 0.53 \\
\hline 45 & 2 & 0.14 & 0.42 \\
\hline
\end{tabular}




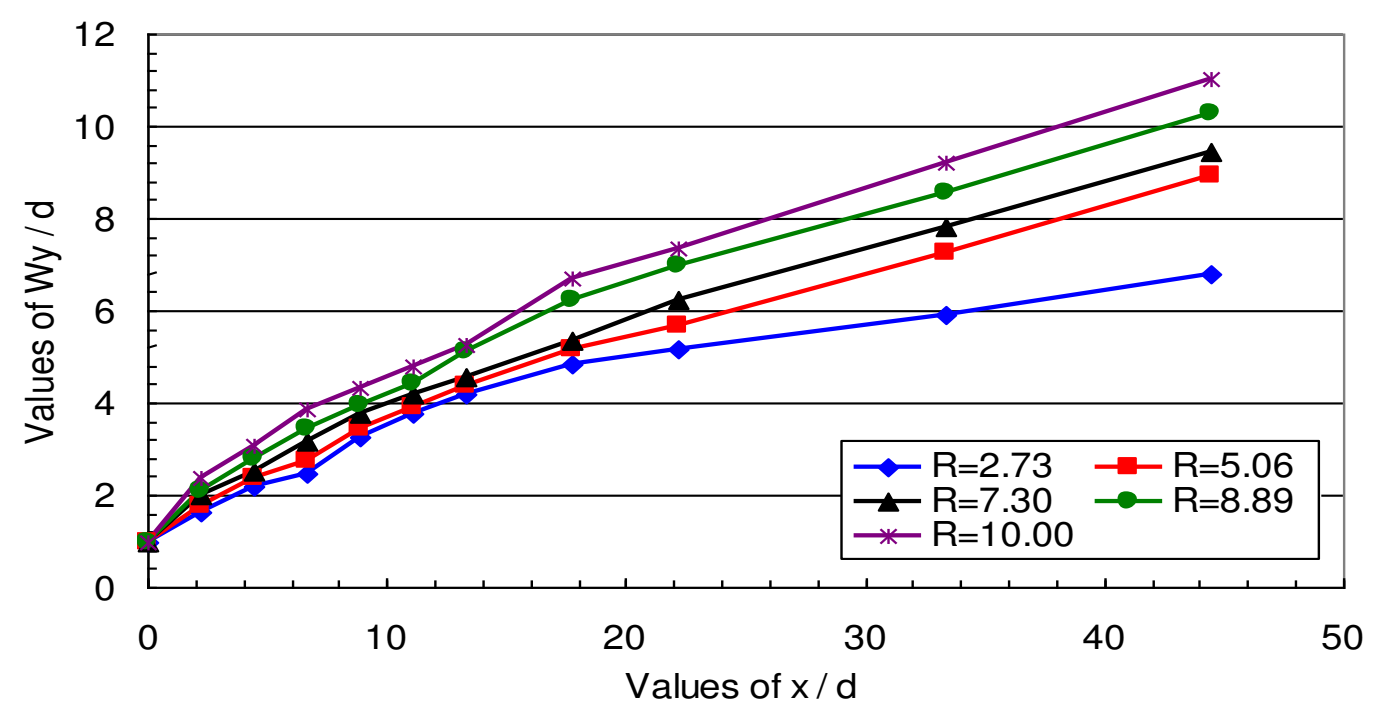

Fig. 10: Relationship between $\mathrm{W}_{\mathrm{y}} / \mathrm{d}$ and $\mathrm{x} / \mathrm{d}$ for different velocity ratios and $\theta=45^{\circ}$.

\section{CONCLUSIONS}

Based on experimental results on studying the hydraulics of surface polluted wall jets discharged at different angles into a cross flow with circular nozzle, it is found that:

1. The trajectory of the jet centerline is dependent on the velocity ratio, angle of inclination to main stream, where a deep penetration is associated with $\theta=90^{\circ}$ and high values of $\mathrm{R}$.

2. The decay of velocity-excess along the jet trajectory depends mainly on traveling distance from the nozzle.

3. Concentration-excess decay is not influenced by the velocity ratio, while it increases with the increase of initial concentrations.

4. The distances at which the concentration reached to $5 \%$ higher than that of the ambient flow is dependent on the angle of inclination, $\theta$.

5. The growth of jet width along the jet trajectory increases with the increase of $\mathrm{R}, \theta$ and traveling distance.

6. Empirical equations are awarded for estimating the jet trajectories, the concentration decay and the jet width.

\section{REFERENCES}

1. Abozeid, G., "Factors influencing the characteristics of surface discharge of heated water jet in open channel", Proc. $1^{\text {st }}$ Int. Water Tech. Conf. (ASCEE-1), Vol. I, No. 1, pp. 618-634, Ain Shams, Cairo, Egypt, 2005.

2. Ali, N. A., "A Contribution to sediment transportation with reference to hydraulic resistance", M. Sc. Thesis, Civil Eng. Dept., Assiut Univ., 1978.

3. Barr, Herbeston, J. G., "A simulation framework of regime theory ", Proc. Of Civil Engrs., Vol. 41, 1986. 
4. Chassaing, P., George, J., Claria, A., and Sananes, F., "Physical characteristics of subsonic jets in a cross-stream", J. Fluid Mech. Vol. 62, pp. 41-64, 1974.

5. Chatlerjee, S. S., and ghosh, S. N., "Submerged horizontal jet over eodible bed", J. of Hyd. Div., ASCE, Vol. 106, 1980.

6. Hodgson, J. E., and Rajaratnam, N., "An experimental study of jet dilution in crossflows", Can. J. Civ. Engrg., Vol. 19, No. 5, pp. 733-743, 1992.

7. Ibrahim, I. M., and Gutmark, E. G., "Dynamics of single and twin circular jets in cross flow", AIAA J. 1281-900, 2006.

8. Jirka, G.H., 1982, "Turbulent buoyant jets in shallow fluid layers", in Turbulent jets and plumes, Rodi, W. (Ed.), Pergamon Press, University of Karlsruhe.

9. Kamotani, Y., and Greber, I., "Experiments on a turbulent jet in a crossflow", AIAA J. 10 (11), 1425-1429, 1972.

10. Keffer, J. F., and Banies, W. D., "The round turbulent jet in a cross wind", J. Fluid Mech., Vol. 15, No. 4, 1963.

11. McGuirk, J. J., and Rodi, W., "A depth-averaged mathematical model for the near field of side discharge into open channel", J. Fluid Mech., Vol. 86, No. 4, 1978.

12. Mohamed, K. A., "Three-dimensional turbulent wall jets in a cross-flow", Ph. D. Thesis Submitted to Inst. Of Tech. Bombay, Indian, 1996.

13. Moussa, Z. M., Trischka, J. W., and Eskinazi, S., "The near field in the mixing of a round jet with cross-stream", J. Fluid Mech., Vol. 80, 1977.

14. Mowad, A. K., Rajaratnam, N., and Stanley, S. J., "Mixing with multiple circular turbulent jets", J. Hydr. Res. Vol. 39, No. 2, 2001.

15. Rajaratnam, N., and Langat, J. K., "Mixing of circular turbulent wall jets in crossflows", J. Hydr. Engrg., ASCE, Vol. 121, No. 10, pp. 694-698, 1995.

16. Salah, E. K., "Surface discharge of warm water from thermal power stations into rivers", proc. 8th Int. Water Tech. Conf. (IWTC8), Alex. Egypt, 2004.

17. Sherif, S. A., "Measurements of the flow thermal characteristics of turbulent jets in crossflow), Ph. D. Thesis, Iowa State University, Iowa, 1985.

18. Wright, S. J., "Effects of ambient crossflows and density stratification on the characteristics behavior of round turbulent buoyant jets", Rep. No. KH-R-36, W. M. Keck Laboratory of Hydraulics and Water Resources, California Inst. of Technology, Calif., 1977.

19. Yuan, L. L., Street, R. L., and Ferziger, J. H., "Trajectory and entrainment of a round jet in crossflow", Phys. Fluids 10: 2323-2335, 1998. 


\section{"السلوك الهيدروليكي لتدفق مائي ملوث خلال السريان بالقتوات المكشوفة"}

يقدم هذا البحث دراسة معملية على بعض العوامل التي تؤثر في الخصائص الهيدروليكية والبيئية لمصب

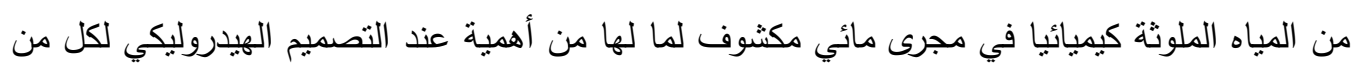

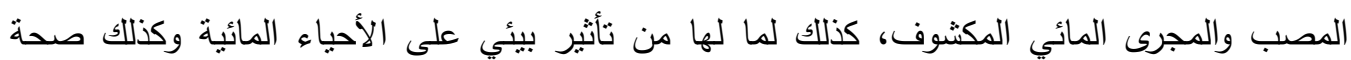
الإنسان والحيوان. أجريت الدراسة بغرض التعرف على الخصائص الهيدروليكية للسريان بالقنوات المكثوفة عند مصب مصدر مائي ملوث كيميائيا من معدل هبوط للسرعات خلال مسار التدفق المائي

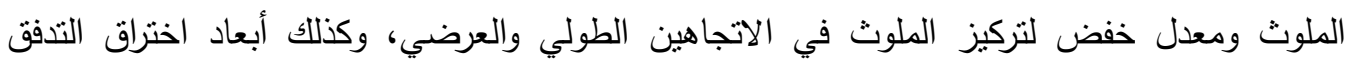
الملوث للمجرى المكثوف وذللك:-

1- بدراسة بعض العوامل المؤثرة في خصائص هذا السريان متل تعير نسبة سرعة اندفاع الملوث

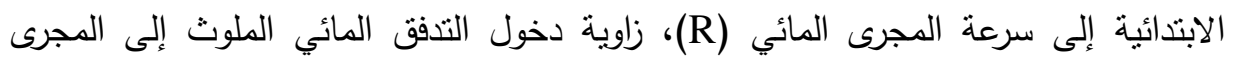

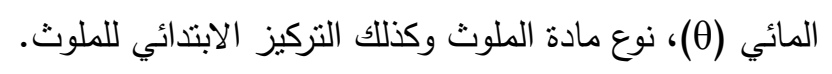

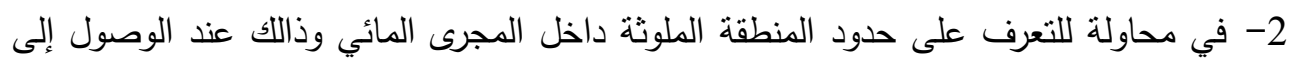

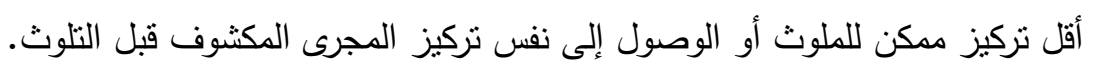

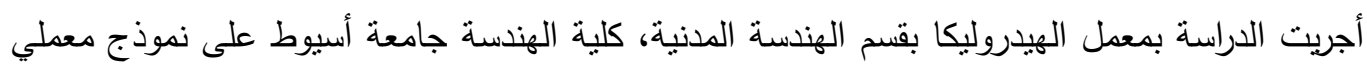

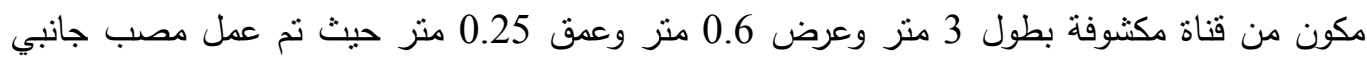

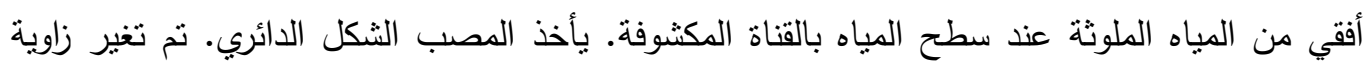

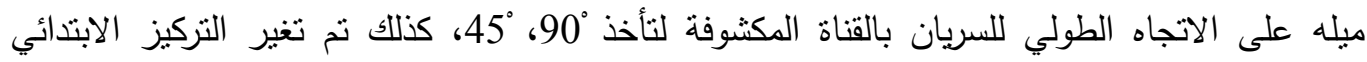
للملوث عدة مرات وأيضا تم تغير نسبة السرعة الابتدائية للتدفق الملوث إلى سرعة المياه بالمجرى لئه

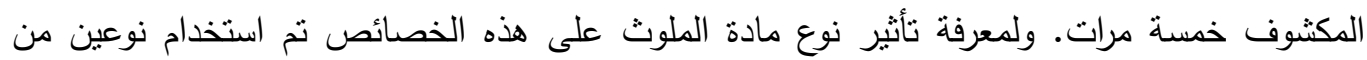

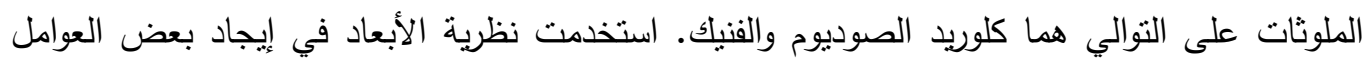
الغير بعدية والمؤثرة في الخصائص الهيدروليكية لهذا المصب والتي بلئ لئي على أساسها تحليل ومناقثنة

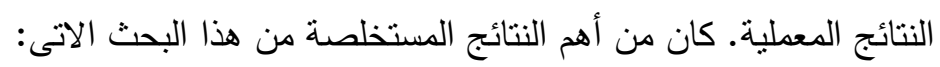

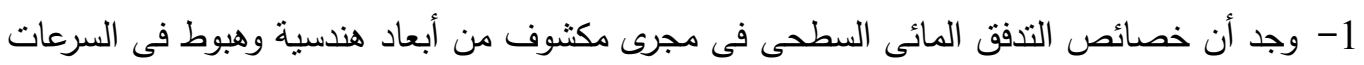
وخفض فى التركيز الكيميائى للملوث يعتمد على العوامل المدروسة (السرعة الابتدائية للتدفق - زاوية

$$
\text { ميل مصدر التدفق - التزكيز الابتدائى للملوث). }
$$

2- وجد أن نوع المادة الكيميائية للملوث لاتؤثر فى خصائص السئى لمريان المتدفق فى المجرى المكثوف. 3- نم استتناج معادلات تجريبية يمكن بواسطتها التعرف على خصائص هذا التدفق المائى الملوث 